\title{
Last millennium environmental changes and climate inferences in the Southeastern Atlantic forest, Brazil
}

\author{
LUIZ C.R. PESSENDA ${ }^{1}$, SORAYA E.M.G. SAIA ${ }^{1}$, \\ SUSY E.M. GOUVEIA ${ }^{1}$, MARIE-PIERRE LEDRU ${ }^{2}$, ABDELFETTAH SIFEDDINE ${ }^{3}$, \\ PAULA G.C. AMARAL ${ }^{4}$ and JOSÉ A. BENDASSOLLI ${ }^{5}$ \\ ${ }^{1}$ Laboratório de Carbono 14, CENA/USP, Av. Centenário, 303, 13416-000 Piracicaba, SP, Brasil \\ ${ }^{2}$ IRD UR 032 “Great Ice" Apartado Postal 17.12.857 Quito, Ecuador \\ ${ }^{3}$ IRD - Institut de Recherche pour le Développement, 32, Av. Henri Varagnat, 93143, Bondy Cedex, France \\ ${ }^{4}$ Instituto de Geociências, USP, Rua do Lago, 562, 05508-080 São Paulo, SP, Brasil \\ ${ }^{5}$ Laboratório Isótopos Estáveis, CENA/USP, Av. Centenário, 303, 13400-970 Piracicaba, SP, Brasil
}

Manuscript received on March 24, 2009; accepted for publication on December 8, 2009

\begin{abstract}
This study presents paleoenvironmental data based on pollen, elemental and isotopic compositions of organic matter (TOC, $\mathrm{N}, \delta^{13} \mathrm{C}$ and $\delta^{15} \mathrm{~N}$ ) and ${ }^{14} \mathrm{C}$ dating of $170 \mathrm{~cm}$ lake sediment record. Samplings have been made in Lagoa Grande at Parque Estadual Turístico do Alto Ribeira - PETAR, Southern São Paulo State, Southeastern Brazil. The variations in relative frequencies (in percentage) of arboreal pollen along the core range between 40 and $80 \%$. The $\delta^{13} \mathrm{C}$ values ranged from $-23 \%$ to $-30 \%$ and $\mathrm{C} / \mathrm{N}$ of $\sim 10$ to 15 , indicating the contribution of terrestrial $\mathrm{C}_{3}$ plants and algae in the sediment organic matter. The $\delta^{15} \mathrm{~N}$ results presented values from 3 to $4.5 \%$, also suggesting a mixture of algae and terrestrial $\mathrm{C}_{3}$ plants. The ${ }^{14} \mathrm{C}$ dating indicates modern age for the shallow horizons to $\sim 1030 \mathrm{BP}$ at the base of the core. A probable wetter climate in the period of $\sim 370 \mathrm{BP}$ to $\sim 340 \mathrm{BP}$ was inferred from the data set, which corresponds to a part of the period covered by the Little Ice Age (LIA).
\end{abstract}

Key words: lacustrine sediment, $\mathrm{C}$ and $\mathrm{N}$ isotopes, pollen, Atlantic Forest, last millennium, Little Ice Age.

\section{INTRODUCTION}

Lake systems are diverse, and the sources and alterations of organic matter are geographically and temporally variable. Nonetheless, useful generalizations can be made about the different kinds of elemental, isotopic and palynologycal proxies that provide evidence of the origins and depositional histories of sedimentary organic matter and hence paleoenvironmental conditions (Meyers 2003).

Pollen records obtained from lacustrine sediments have been used for palaeoenvironmental reconstruction studies during the late Quaternary and the Holocene in several regions of South America and Brazil (Absy and

Correspondence to: Luiz Carlos Ruiz Pessenda

E-mail: pessenda@cena.usp.br van der Hammen 1976, Absy et al. 1991, Roth and Lorscheitter 1993, van der Hammen and Absy 1994, Colinvaux et al. 1996, Ledru et al. 1996, 2001, 2002, Behling 1995a, b, 1997a, b, 1998, 2002, Salgado-Labouriau et al. 1998, Sifeddine et al. 2001, 2003, Saia 2006). Considering the last $3000 \mathrm{BP}$, most of the records indicate increased moisture conditions, although differences in climatic signal are recorded according to the site location. However, no data have been produced in high resolution emphasizing the potential use of an interdisciplinary study, involving different proxies and techniques for the last millennium.

Interdisciplinarity is fundamental for improving interpretations. In most cases, analysis of the bulk composition of sedimentary organic matter will provide only 
general information. In fact, according to Meyers (2003), Sifeddine et al. 2004 and Ortiz et al. 2004, interpretation is not simple, in most cases, organic matter is a mixture of components from many sources and with variable degrees of preservation. Despite diagenesis, partial reworking and alteration of the original organic matter when sinking to the lake bottom, sedimentary organic matter retains important information on its origin, transportation and deposition, which helps paleoenvironmental reconstructions (Ortiz et al. 2004).

The $\delta^{13} \mathrm{C}$ values of lacustrine sedimentary organic matter may potentially reflect changing proportions of different types of vegetal matter (e.g. $\mathrm{C}_{3}$ vs. $\mathrm{C}_{4}$ plant abundance), as well as the presence of aquatic organisms, e.g. phytoplankton, which have similar isotopic signatures (Meyers 1997). During photosynthesis, phytoplankton preferentially utilizes the ${ }^{12} \mathrm{C}$ isotope, leading to typical $\delta^{13} \mathrm{C}$ values of $-20 \%$ in its organic matter (Meyers 2003, Schidlowski et al. 1994). Thus, when the phytoplankton utilizes the dissolved $\mathrm{CO}_{2}$ in equilibrium with the atmosphere, it is usually an isotope indistinguishable from organic matter produced by terrestrial $\mathrm{C}_{3}$ plants. The correlation with $\mathrm{C} / \mathrm{N}$ (total organic carbon and total organic nitrogen ratio) values is useful. $\mathrm{C} / \mathrm{N}$ ratio of lacustrine sediments can be used to distinguish two main types of organic matter: (i) organic matter without cellulosic structure, originated from algae and phytoplankton, characterized by ratios between 4 and 10; and (ii) organic matter with cellulosic structure, produced by terrestrial plants, characterized by ratios $\geq 20$ (Meyers and Ishiwatari 1993, Meyers 1994). This correlation should thus lead to discrimination between organic matter from freshwater algae and organic matter from $\mathrm{C}_{3}$ or $\mathrm{C}_{4}$ type plant sources. Analysis of stable carbon isotopes and the $\mathrm{C} / \mathrm{N}$ ratio of organic matter preserved within lake sediments can provide important information about paleoenvironments, which can serve to complement pollen-based paleovegetation studies.

Although not widely used as a paleolimnological proxy as $\delta^{13} \mathrm{C}$ values, nitrogen isotopic compositions $\left(\delta^{15} \mathrm{~N}\right)$ can similarly help to identify sources of organic matter of lakes and to reconstruct past productivity rates (Lent et al. 1995, Herczeg et al. 2001). The isotopic difference among sources of nitrogen is roughly preserved in the $\delta^{15} \mathrm{~N}$ values of organic matter from algae $(+8.5 \%)$ and from $\mathrm{C}_{3}$ terrestrial plants $(+0.5 \%)$ (Peterson and Howarth 1987).

This study shows the first lake sediment record regarding the last millennium in Brazil. The main objective is the reconstruction of the vegetation changes in high resolution, with climate inferences that occurred in Southeastern Brazil during the last millennium. The data were obtained from a sediment record using pollen, geochemistry (total organic carbon - TOC and total nitrogen $-\mathrm{TN})$ and isotope $\left(\delta^{13} \mathrm{C}\right.$ and $\left.\delta^{15} \mathrm{~N}\right)$ analysis, in addition to a detailed chronological frame based on radiocarbon dates. We did inferences with the period of the Little Ice Age (LIA) that occurred among $14^{\text {th }}$ and $19^{\text {th }}$ centuries and the Maunder Minimum (1645-1715 AD).

\section{STUDY AREA}

Lagoa Grande is a small lake located at PETAR (Parque Estadual Turístico do Alto Ribeira; (2431'59.1' S, $48^{\circ} 39^{\prime} 45.0^{\prime \prime} \mathrm{W}, 364$ m elevation), Vale do Ribeira, South of São Paulo State (Fig. 1). This park is a conservation unit on the left bank of the Ribeira River, approximately $350 \mathrm{~km}$ from the city of São Paulo, and $100 \mathrm{~km}$ from the Atlantic coastline. The lake developed within a centripetal drainage basin on karst topography. The catchment area is about $10000 \mathrm{~m}^{2}$ and the lake itself occupies an area of about $150 \mathrm{~m}^{2}$, with a present maximum water depth of $1 \mathrm{~m}$. The lake, which is situated in a remote region, contains largely untouched natural sediments. Bedrock geology consists of a sequence of low-grade metasedimentary rocks of the Late Proterozoic Açungui Group, which is formed by fine-graded limestones interbedded mainly with metasiltites and phyllites (Campanha and Sadowski 1999). The major minerals in these rocks are calcite, quartz, mica and chlorite. The clayey soils are classified as cambisols.

The mean annual temperature is $20^{\circ} \mathrm{C}$, with minimum and maxima of 14 and $27^{\circ} \mathrm{C}$, respectively. The average annual precipitation is around $1600 \mathrm{~mm}$ (Karmann 1994), with low rainfall from June to August.

The natural vegetation around Lagoa Grande is the Atlantic Dense Ombrophilous Forest (forest hillside) and lies within the Atlantic Forest domain of vegetation. The modern vegetation in the lake margins is occupied mainly by trees of the family Cecropiaceae, Euphorbiaceae, Flacourtiaceae, Lauraceae, Leguminosae, 


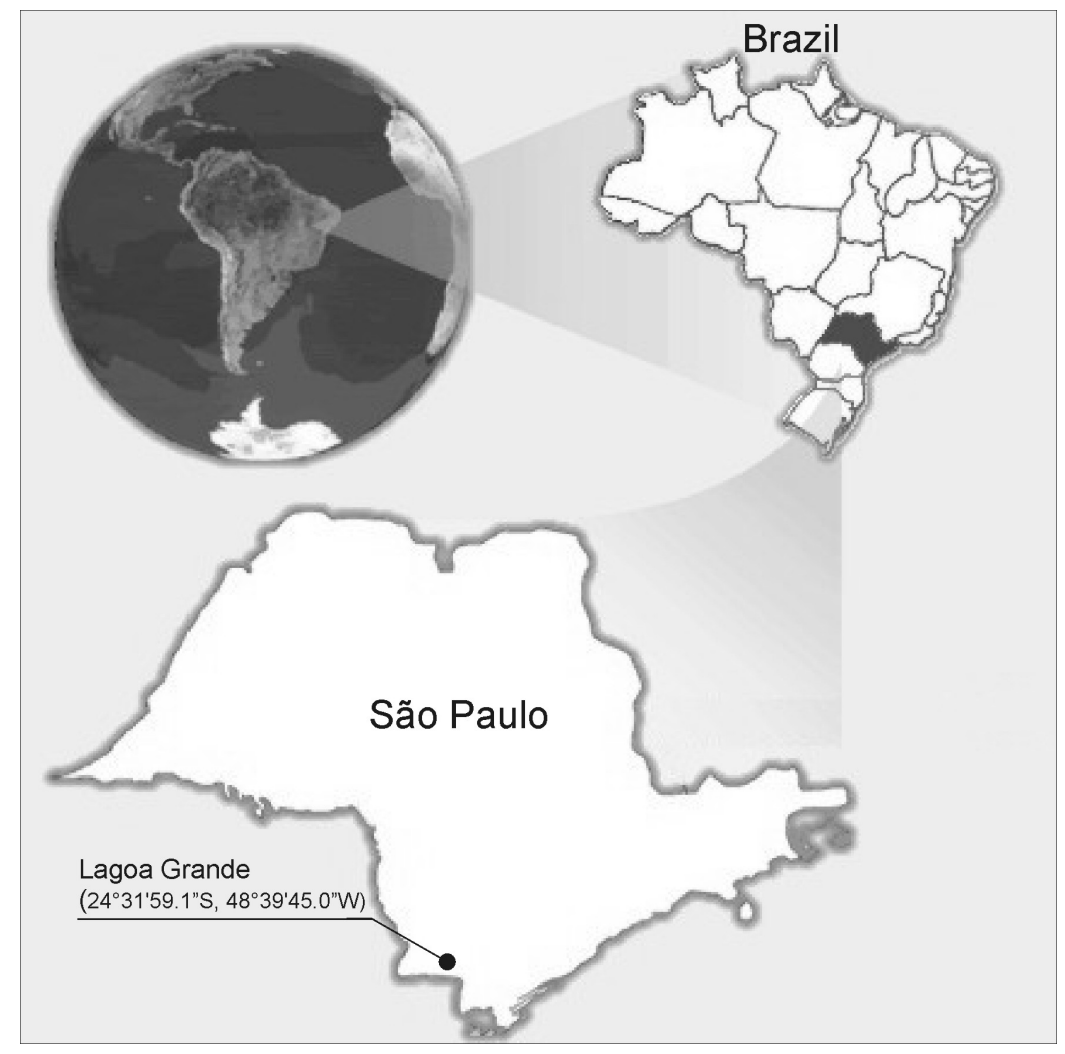

Fig. 1 - Location of the study area.

Melastomataceae, Meliaceae, Monimiaceae, Moraceae, Myristicaceae, Myrtaceae, Rubiaceae, Sapindaceae and Sapotaceae.

\section{MATERIALS AND METHODS}

SAmpling ANd ANalytical Procedures

A sediment core was collected using a vibracorer (Martin et al. 1995) and a 3-inch diameter aluminum tube with $3 \mathrm{~m}$ length. The $170 \mathrm{~cm}$ long core was collected close to the lake margin and sub-sampled in 2 to $10 \mathrm{~cm}$ intervals for analysis.

\section{AND N IsOTOPES}

The sediment samples separated of leaves, roots, etc., were treated with $\mathrm{HCl} 4 \%$ to eliminate carbonates, washed with distilled water up to $\mathrm{pH} 6$, dried at $50^{\circ} \mathrm{C}$ and homogenized. These samples were used for total organic carbon and nitrogen analyses, carried out at the Stable Isotope Laboratory of Center for Nuclear Energy in Agriculture (CENA/USP). The results were expressed in percentage of dry weight, with analytical precision of
0.09 and $0.07 \%$, respectively. The ${ }^{13} \mathrm{C}$ and ${ }^{15} \mathrm{~N}$ results were expressed as $\delta^{13} \mathrm{C}$ and $\delta^{15} \mathrm{~N}$ with respect to the PDB standard and atmospheric air, respectively, using the conventional notations:

$$
\begin{aligned}
\delta^{13} \mathrm{C}_{\text {Sample }} & =\frac{\mathrm{R}_{\mathrm{S} 1}-\mathrm{R}_{\mathrm{PDB}}}{\mathrm{R}_{\mathrm{PDB}}} \times 1000 \\
\delta^{15} \mathrm{~N}_{\text {Sample }} & =\frac{\mathrm{R}_{\mathrm{S} 2}-\mathrm{R}_{\text {Air }}}{\mathrm{R}_{\text {Air }}} \times 1000
\end{aligned}
$$

where $R_{\mathrm{S} 1}$ and $\mathrm{R}_{\mathrm{S} 2}$ are, respectively, the ${ }^{13} \mathrm{C} /{ }^{12} \mathrm{C}$ and ${ }^{15} \mathrm{~N} /{ }^{14} \mathrm{~N}$ ratios in the sample, $R_{\mathrm{PDB}}$ the ${ }^{13} \mathrm{C} /{ }^{12} \mathrm{C}$ ratio for the international standard (PDB) and $\mathrm{R}_{\text {Air }}$ the ${ }^{15} \mathrm{~N} /{ }^{14} \mathrm{~N}$ ratio for the atmospheric air. The results were expressed in delta per mil notation, with analytical precision better than $0.2 \%$ (Pessenda et al. 2004, 2005).

For radiocarbon analyses, wood fragments and bulk sediment samples were subjected to physical treatment (removal of vegetable remains, etc.) and treated with $\mathrm{HCl} 4 \%$ for $4 \mathrm{~h}$ at $60^{\circ} \mathrm{C}$ to remove carbonates, fulvic acids and resins. After successive washes (up to $\mathrm{pH}$ 5) with deionised water and drying to $60^{\circ} \mathrm{C}$ for $48 \mathrm{~h}$, the samples were combusted and the purified $\mathrm{CO}_{2}$ 
sent to the Isotrace Laboratory, University of Toronto, Canada, for Accelerator Mass Spectrometry (AMS). Radiocarbon ages (Table II) are expressed as ${ }^{14} \mathrm{C}$ BP (years Before Present) and in cal BP (calibrated years Before Present) (Stuiver et al. 1998) and with precision of $\pm 2 \sigma$.

\section{PALINOLOGY}

The pollen analyses were performed each at $10 \mathrm{~cm}$ interval along the $160 \mathrm{~cm}$ long core. Chemical treatment of approximately $5 \mathrm{~g}$ of sediment was performed for pollen extraction based on Faegri and Iversen (1989). Sample treatment followed the Lüber technique using 70\% HF for $18 \mathrm{~h}$, followed by $50 \% \mathrm{HCl}$ in hot water bath and by $10 \% \mathrm{KOH}$ solution. Palynomorphs were separated using $\mathrm{ZnCl}_{2}$ and the residue fraction of $50 \mu \mathrm{L}$ mounted on microscope slides in silicon oil; pollen counting was performed under $1000 \times$ magnification. Approximately 300 pollen grains of tree and herb taxa were counted per sample. The reference collection of Dr. Marie-Pierre Ledru and pollen atlas were used for pollen identification (Absy 1975, Markgraf and D’Antoni 1978, Colinvaux et al. 1999). Frequencies are expressed as percentages of the total sum of arboreal pollen (AP), nonarboreal pollen (NAP) and undetermined types, with aquatic taxa, fern spores and Cyperaceae excluded from the total sum. Relative frequencies of spores and aquatic taxa were calculated in relation to the total AP and NAP sums. The determination of pollen concentration was based on the method of Cour (1974), following the mathematical equation:

$$
f(\%)=\frac{V}{V} \times \frac{I}{L} \times 100
$$

where:

$$
\begin{aligned}
\mathrm{V}= & \text { volume of the residue used in the feature of } \\
& \text { pollen slides; } \\
\mathrm{V}= & \text { total volume of the residue after a chemical } \\
& \text { treatment; } \\
\mathrm{I}= & \text { total length observed in the slides during the } \\
& \text { counting of grains; } \\
\mathrm{L}= & \begin{array}{l}
\text { medium length used in each slide, defined for } \\
\text { the longitudinal lines between the residue and }
\end{array} \\
& \text { the glue line that was traced in the slide. }
\end{aligned}
$$

The residue percentage in each sample is obtained from this calculation. From the fraction observed in each residue ( $\mathrm{f} \%$ ), it is possible to calculate the grain concentration per gram of sediment. This calculation is obtained from the next equation:

$$
r=\frac{n \times(100 / f)}{m}
$$

where:

$$
\begin{aligned}
\mathrm{n}= & \text { total sum of grains in one slide; } \\
\mathrm{f}= & \text { fraction observed in the residue; } \\
\mathrm{m}= & \text { original weight used in the chemical treatment } \\
& \text { of the sample. }
\end{aligned}
$$

\section{RESULTS}

The core sediment consists of grey dark clay with massive structure at the bottom, changing upward to planeparallel lamination of brown and grey clay mud, to light brown mud with massive structure and red spots (iron/ hydroxide/oxide), to plane-parallel lamination of brown and grey clay mud, to light brown mud with massive structure and red spots, and to light brown and massive structure without bioturbation at the surface (Fig. 2, Table I).

The ages of terrestrial macrofossils (wood fragments) and sediment samples ranged from $1030 \pm 60 \mathrm{BP}$ at $171-168 \mathrm{~cm}$ to modern ages (8-6 cm sediment depth), with increasing ages downward (Fig. 2, Table II). At $126-116 \mathrm{~cm}$ a wood fragment presented an age of 680 $\pm 80 \mathrm{BP}$, and at $124-122 \mathrm{~cm}$ the organic sediment sample an age of $550 \pm 50 \mathrm{BP}$. Similar results were obtained for the wood fragment $(250 \pm 60 \mathrm{BP})$ at $65-63 \mathrm{~cm}$, and for the organic sediment sample $(320 \pm 60 \mathrm{BP})$ at $64-$ $62 \mathrm{~cm}$. In order to provide age estimation relative to sediment depth, a continuous age scale based on interpolation of ${ }^{14} \mathrm{C}$ ages versus sediment depth is presented in Figure 3 .

The results of the pollen analysis are presented in Figures 2 and 4 . Figure 2 shows changes in arboreal pollen and spores frequencies and the concentration values of number of pollen grains per gram of wet sediment. The main pollen types found in the sediment of Lagoa Grande are associated to Cyperaceae and Poaceae, which record the vegetation at the lake margin, and Alchornea, 


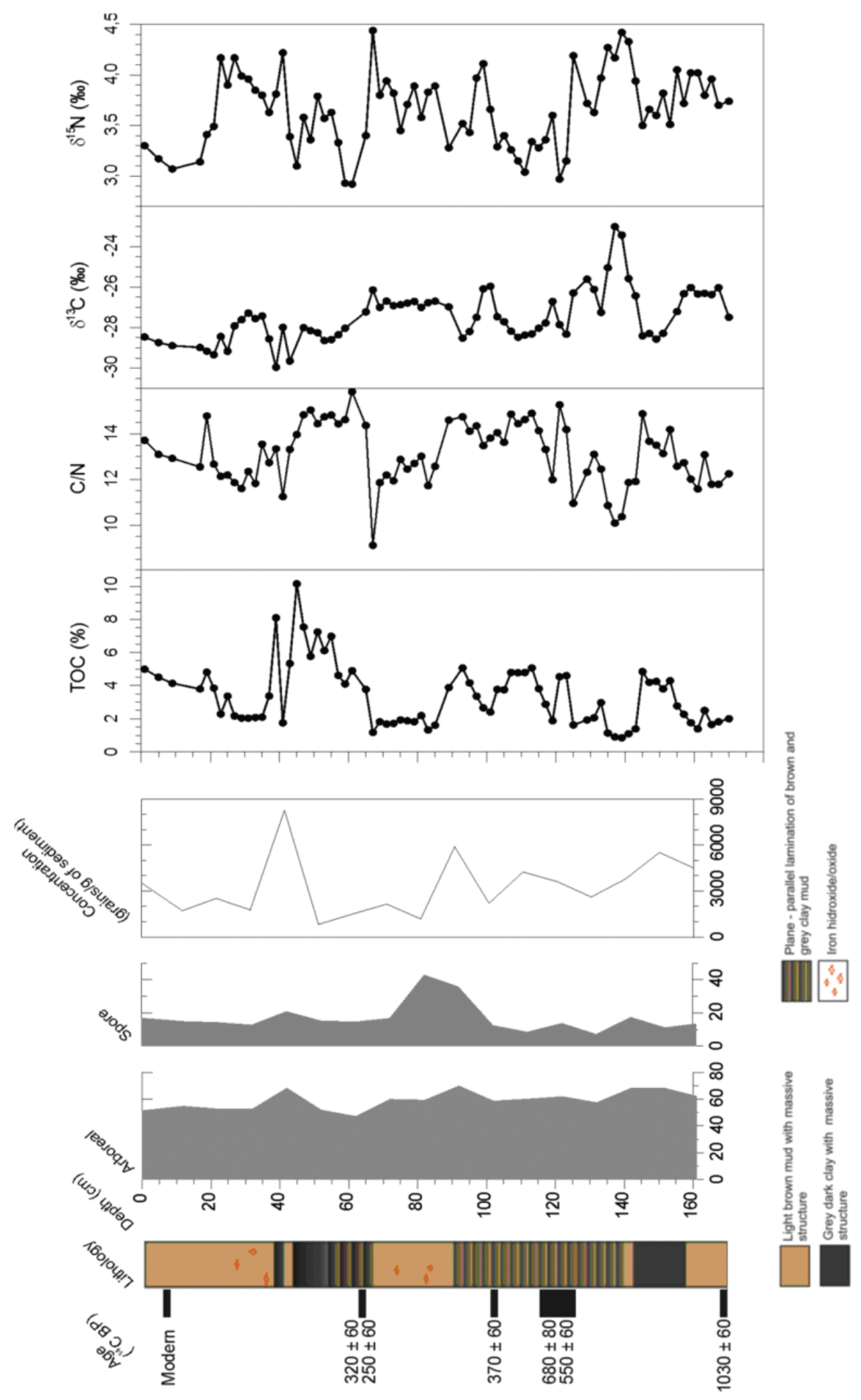

Fig. 2 - Concentrations of arboreal pollen, spore, grains/g of sediment, total organic carbon, $\mathrm{C} / \mathrm{N}$ ratios, $\delta^{13} \mathrm{C}$ and $\delta^{15} \mathrm{~N}$ values from Lagoa Grande. 
TABLE I

Stratigraphic description of the Lagoa Grande core.

\begin{tabular}{c|l}
\hline Depth $(\mathrm{cm})$ & \multicolumn{1}{|c}{ Description } \\
\hline $0-25$ & Light brown mud with massive structure without bioturbation \\
\hline $25-41$ & light brown mud with massive structure; presence of iron/hydroxide/oxide \\
\hline $41-67$ & plane - parallel lamination of brown and grey clay mud \\
\hline $67-88$ & light brown mud with massive structure; presence of iron/hydroxide/oxide \\
\hline $88-137$ & plane - parallel lamination of brown and grey clay mud \\
\hline $137-170$ & grey dark clay with massive structure \\
\hline
\end{tabular}

TABLE II

${ }^{14} \mathrm{C}$ ages of organic matter obtained in the Lagoa Grande core.

\begin{tabular}{c|c|c|c|c}
\hline Sample & $\begin{array}{c}\text { Depth } \\
(\mathrm{cm})\end{array}$ & $\begin{array}{c}\text { Laboratory } \\
\text { number }\end{array}$ & $\begin{array}{c}{ }^{14} \mathrm{C} \text { Age } \\
(\mathrm{BP})\end{array}$ & $\begin{array}{c}{ }^{14} \mathrm{C} \text { Age } \\
(\mathrm{cal} \mathrm{BP}), 2 \sigma\end{array}$ \\
\hline Organic matter & $6-8$ & TO-11372 & Modern & $1958-1959 *$ \\
\hline Organic matter & $62-64$ & TO-11373 & $320 \pm 60$ & $1448-1665$ \\
\hline Wood fragment & $63-65$ & TO-10874 & $250 \pm 60$ & $1468-1695$ \\
\hline Organic matter & $100-102$ & TO-11374 & $370 \pm 60$ & $1440-1643$ \\
\hline Wood fragment & $116-126$ & TO-10875 & $680 \pm 80$ & $1209-1424$ \\
\hline Organic matter & $122-124$ & TO-11375 & $550 \pm 60$ & $1296-1443$ \\
\hline Organic matter & $168-171$ & TO-11376 & $1030 \pm 60$ & $890-1155$ \\
\hline
\end{tabular}

TO - Isotrace Laboratory, Toronto, Canada; $(*)$ - cal AD.

Cecropia, Myrtaceae and Moraceae, and Podocarpus and Weinmannia, which are elements of Atlantic Ombrophilous forest and of forest of altitude, respectively.

The predominance of arboreal taxa is observed along all the sediment core (Fig. 2). From 170-140 cm depth ( $\sim 1000$ BP to $\sim 750 \mathrm{BP})$, arboreal pollen frequencies are high, with $\sim 70 \%$ and a peak of fern spores of $\sim 20 \%$ is being observed. Cecropia, Moraceae, Myrtaceae and Poaceae are also recorded. The frequency of Weinmannia and Alchornea is high (Fig. 4). Weinmannia shows the highest frequency of this interval, with $7 \%$, and Podocarpus appears around $150 \mathrm{~cm}$. In the interval $155 \mathrm{~cm}$ to $145 \mathrm{~cm}(\sim 950$ to $800 \mathrm{BP})$, the TOC content increased from 1.8 to $5.0 \%$, the $\mathrm{C} / \mathrm{N}$ ranged from 12.6 to 14.9 , the $\delta^{13} \mathrm{C}$ values stayed around $-28.5 \%$ and $\delta^{15} \mathrm{~N}$ values ranged from $3.3 \%$ to $3.8 \%$ (Fig. 2). The results are indicative of the predominance of organic matter from terrestrial $\mathrm{C}_{3}$ plants. From $145 \mathrm{~cm}$ to $135 \mathrm{~cm}$ ( $\sim 800 \mathrm{BP}$ to $720 \mathrm{BP})$, the TOC values decreased from $5 \%$ to $0.5 \%$, the $\mathrm{C} / \mathrm{N}$ from 14.9 to 10 , the $\delta^{13} \mathrm{C}$ values enriched from $-28.5 \%$ to $-23.7 \%$, and $\delta^{15} \mathrm{~N}$ values in- creased from $3.5 \%$ to $4.5 \%$, which is indicative of more significant presence of phytoplankton (algae) (Meyers 1994). This could be associated with the increase of the lake level due to more humid conditions than the previous period. From $135 \mathrm{~cm}$ to $70 \mathrm{~cm}$ depth $(\sim 720 \mathrm{BP}$ to $\sim 320 \mathrm{BP}$ ), the elemental and isotopic analyses (TOC ranged from 0.8 to $5.1 \%$, the $\mathrm{C} / \mathrm{N}$ ratio from 10.1 to $15.3, \delta^{13} \mathrm{C}$ values from $-23.7 \%$ to $-29 \%$, and $\delta^{15} \mathrm{~N}$ from $4.25 \%$ to $3 \% 0$ ) indicated a mixture of organic matter $\left(\mathrm{C}_{3}\right.$ plants and phytoplankton), with higher influence of terrestrial $\mathrm{C}_{3}$ plants. From $135 \mathrm{~cm}$ to $80 \mathrm{~cm}(\sim 720 \mathrm{BP}$ to $\sim 350 \mathrm{BP})$, a decrease of Alchornea $(\sim 2 \%)$ and $\mathrm{Ce}$ cropia $(\sim 0.5 \%)$ was observed, and the Podocarpus disappeared till $\sim 110 \mathrm{~cm}(\sim 420$ BP $)$. From 80 to $70 \mathrm{~cm}$ $(\sim 350$ BP to $\sim 320 \mathrm{BP})$, the spore frequencies presented the highest value (up to $\sim 50 \%$ ) (Fig. 4), which is coincident with the significant increase of Weinmannia (4\%), Podocarpus (0.8\%), Cyperaceae ( $\sim 4$ to $5 \%$ ) and Myrtaceae $(28 \%)$ at $90 \mathrm{~cm}(\sim 360 \mathrm{BP})$. From 70 to $50 \mathrm{~cm}$ depth ( $\sim 320$ BP to $\sim 280 \mathrm{BP})$, the TOC increased up to $8 \%$, the $\mathrm{C} / \mathrm{N}$ values to 15 being associated with more 
depleted $\delta^{13} \mathrm{C}(-29 \%)$, and $\delta^{15} \mathrm{~N}$ ranged between $\sim 3 \%$ and $3.5 \%$, indicating a mixture of organic matter $\left(\mathrm{C}_{3}\right.$ plant and algae). A decrease of arboreal pollen frequency from $\sim 60 \%$ to $55 \%$ was observed at $\sim 60 \mathrm{~cm}(\sim 300 \mathrm{BP})$, simultaneously with Alchornea (4\%), Myrtaceae (10\%), Podocarpus (0.25\%) and Weinmannia (2\%). The spore frequency was around $10 \%$ (Fig. 4).

From $50 \mathrm{~cm}$ to top ( $280 \mathrm{BP}$ to the present) the TOC contents ranged from 10 to $1.7 \%, \mathrm{C} / \mathrm{N}$ values from 15 to $11, \delta^{13} \mathrm{C}(-27$ to $-30 \%)$, and $\delta^{15} \mathrm{~N}$ values from 3 to $4.25 \%$ (Fig. 2), suggesting a mixture of organic matter originated from $\mathrm{C}_{3}$ terrestrial plants and phytoplankton (Meyers 1994). From 50 to $25 \mathrm{~cm}$ ( $\sim 280 \mathrm{BP}$ to $\sim 180 \mathrm{BP}$ ), an increase was observed in the arboreal pollen (up to $70 \%$ ), spores (25\%), Alchornea (10\%), Poaceae (20\%), Moraceae (8\%) and in the grains/g of sediment. Simultaneously, this increase is accompanied by a decrease in the frequencies of Cecropia $(0.5 \%)$, Podocarpus ( $0.25 \%$ ) and Weinmannia (1\%). From $\sim 25$ $\mathrm{cm}$ to top ( $\sim 180$ BP to the present), the total arboreal pollen frequencies are around $60 \%$ and the spore frequencies of $\sim 15 \%$ at $15 \mathrm{~cm}$. Alchornea (from 4 to $1 \%$ ) and Weinmannia (1\%) remained low, Myrtaceae (10\%) and Poaceae (20\%) remained constant, and Podocarpus (up to 1.5\%), Cecropia (up to 2.5\%) and Moraceae (up to $11 \%$ ) increased.

The distribution of $\mathrm{C} / \mathrm{N}$ versus $\delta^{13} \mathrm{C}$ values (Fig. 5) indicates the presence of two sources of organic matter. Very few samples indicate a more significant presence of algae and most of the samples represented a mixture of algae and terrestrial $\mathrm{C}_{3}$ plants, probably associated with the variation of the lake level.

\section{DISCUSSION}

The pollen record of Lagoa Grande indicates no drastic changes in the arboreal vegetation, suggesting that the climate of the area, at least in the last millennium, remained humid in most of the period, probably without longer dry seasons. The pollen types found from $\sim 1000$ BP to $\sim 400$ BP are characteristic of dense and humid forest represented by Alchorneae, Cecropia, Myrtaceae and Moraceae, of local plants on the lake margins such as Cyperaceae and Poaceae, of spores with frequency of up to $\sim 15-20 \%$, and of elements of forest of altitude indicated by the low presence $(<0.5 \%)$ of Podocarpus at $\sim 820 \mathrm{BP}$ and $380 \mathrm{BP}$, and more significant frequency ( $\sim 4 \%$ and $\sim 6 \%$, respectively) of Weinmannia.

An increase in the frequency of spores up to $50 \%$ is observed at $\sim 350 \mathrm{BP}$. One hypothesis could be linked with the oxidation and degradation of more fragile pollen types, resulting in a relative enrichment of more resistant pollens, such as spores (Colinvaux et al. 1999). However, oxidation signs or bad preservation were not observed in the pollen content. The second hypothesis is associated with the decrease of the water level, probably related with a warmer and/or drier climate period, and with consequent wider exposure of the lake margins. Fern spores and Cyperaceae, usually found in lake margins, simultaneously increased their frequencies, which were recorded between $\sim 400$ and 320 BP (Fig. 4). A third hypothesis is also possible: an increase in both humidity and erosion process, with the consequent input of fern spores and Cyperaceae, usually found in humid environments, into the lake basin. Geochemical interpretation presented by Oliveira et al. 2009 supports this last hypothesis. According to these authors, the composition of the Lagoa Grande sediments can be described in terms of a dominant geogenic component, an association of mica, kaolinite and goethite with elements of low mobility during weathering $(\mathrm{Ba}, \mathrm{Cs}, \mathrm{Rb}, \mathrm{Sr})$, and with elements commonly assumed to be immobile (Ti, $\mathrm{Cr}, \mathrm{Sc}, \mathrm{Zr}$, Hf and Ta). This component may have been brought by erosion and removal of deeper soil layers in the catchment area, where these elements are found at the highest abundance and largely derived from the B-horizon of the surrounding soil profiles. In addition, there is a minor biogenic component and related to the O-horizon (shallow layers) of these soils, which reflects the association of chlorite with the transition metals (Co, $\mathrm{Zn}$ and $\mathrm{Cu}$ ). This probably represents the input into the lake of material eroded from the uppermost organic horizons of the catchment soils. In the O-horizon of soils, many metals are found forming stable organo-metallic compounds. This is particularly the case for $\mathrm{Zn}$ and $\mathrm{Cu}$, which are among the most essential elements for plant growth and is accumulated in the humus layer (Blaser et al. 2000). This component is relatively more concentrated in the uppermost (360 BP to present) and lowermost zones (1030 to $730 \mathrm{BP}$ ) of the sedimentary column than in the intermediate zone (730 to $360 \mathrm{BP}$ ). A possi- 


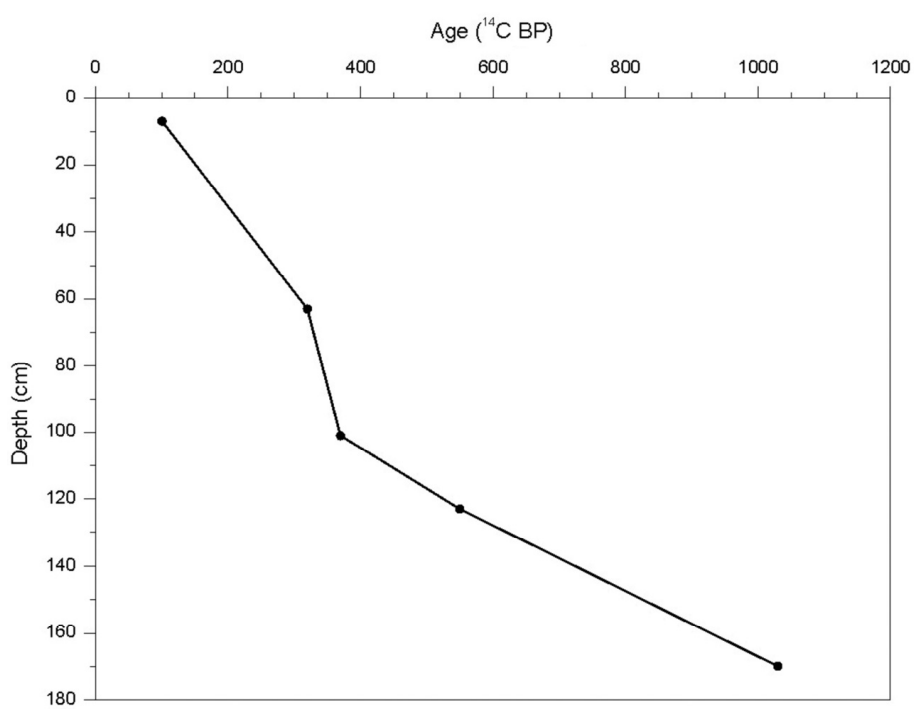

Fig. 3 - Age in relation to sediment depth.

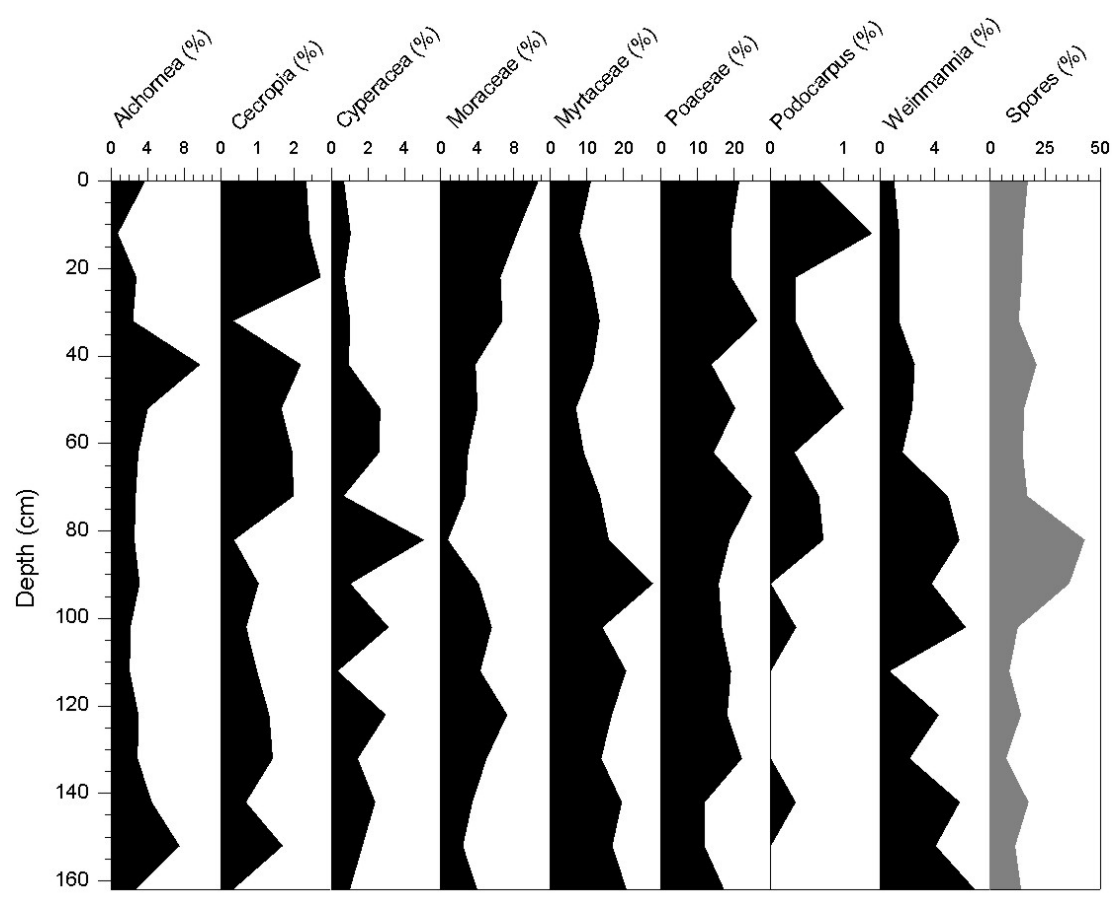

Fig. 4 - Percentage of Alchornea, Cecropia, Cyperaceae, Moraceae, Myrtaceae, Poaceae, Podocarpus, Weinmannia and spores from Lagoa Grande.

ble cause for this is the variation in the erosion regime in the catchment area. At the onset of the sedimentation (1030 to $730 \mathrm{BP}$ ), the input of deeper layers of soil was reduced as a result of the relative catchment stability. Under such conditions, a greater proportion of biogenic elements was accumulated in the sediments. With the increase in the erosion intensity between 730 to $360 \mathrm{BP}$, deeper layers of the soil profile were successively eroded. The inflow of those materials into the lake led to a relative depletion of the biogenic component of the sediments. This trend was enhanced between 490 to $360 \mathrm{BP}$. From 360 BP onwards the concentration of the biogenic component in the sediments increased again, suggesting the resumption of more stable conditions in the catch- 


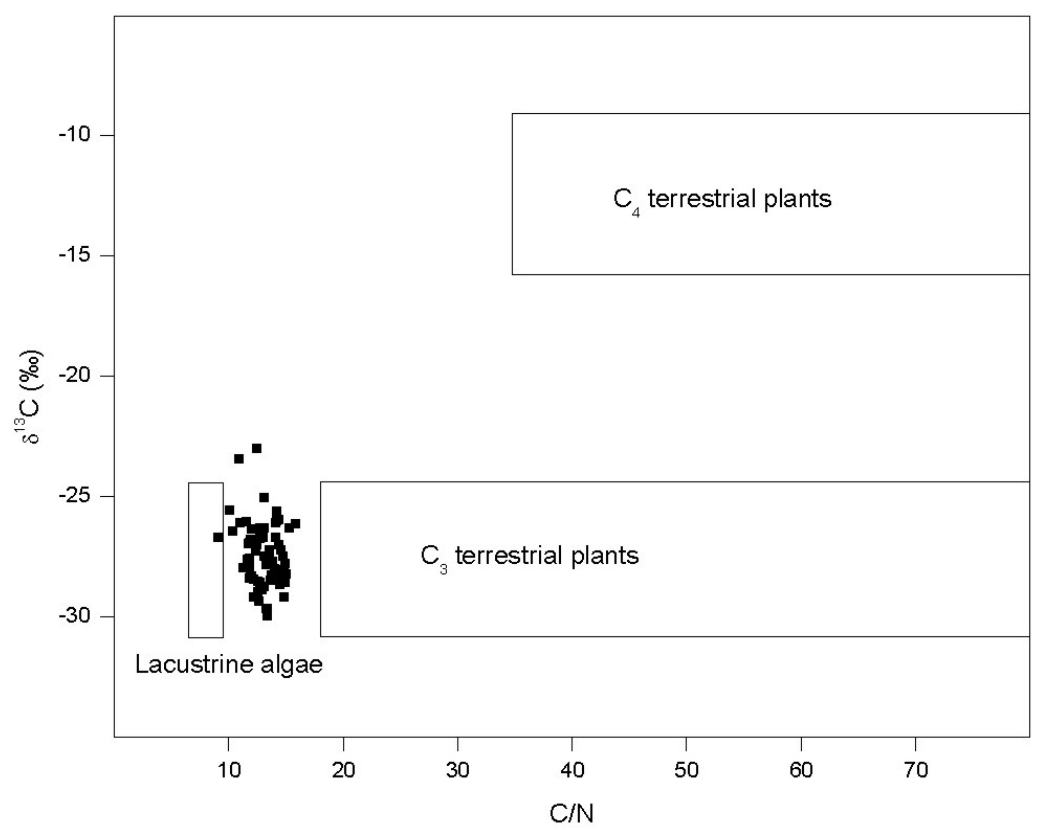

Fig. $5-\mathrm{C} / \mathrm{N} \times \delta^{13} \mathrm{C}$.

ment area, except for brief episodes of enhanced erosion around $340 \mathrm{BP}, 280 \mathrm{BP}$ and 200 to $170 \mathrm{BP}$.

The changes in the erosion regime can be assumed to be controlled by climate fluctuations. A shift toward increased rainfall, particularly if it occurs in the summer months increasing the seasonality and enhancing erosion in the catchment area. This would increase the supply of geogenic material into the lake, diluting the material from the more organic topsoil.

A link can thus be established between the geochemical signature of the sediments and the climatic conditions at the time of their deposition. During the last millennium, in the Lagoa Grande region, the period inferred from the geochemical data from 730 to $360 \mathrm{BP}$ (wetter), with the wettest conditions between 490 and 360 BP, overlaps approximately that one suggested by pollen and isotopic data (see the following discussion) as a warmer (inference from pollen) and wetter (inferences from both indicators) period of $\sim 370$ to $340 \mathrm{BP}$. Therefore, the hypothesis of an increase in both humidity and erosion process, with the consequent input of fern spores and Cyperaceae, will be considered. Concerning the elemental and isotope data, it was observed in the interval $\sim 370$ to $340 \mathrm{BP}$ an increase in the concentration of grains/g of sediment, TOC concentration, $\mathrm{C} / \mathrm{N}$ values, and a depletion of $\delta^{13} \mathrm{C}$, which is indica- tive of significant input of organic matter of $\mathrm{C}_{3}$ plant, probably associated with the increase of spores of Cyperaceae and arboreal species as Myrtaceae and Weinmannia, during more humid and erosive period (Fig. 2). In the interval $\sim 340$ to $320 \mathrm{BP}$, it was observed the lowest values of TOC in the whole sediment profile, as well as the lowest grain per gram of sediment, which could be connected with a small input of the organic matter in the sedimentary basin, possibly associated with a less humid and erosive period. At the same time, a significant increase in Weinmannia frequencies is observed (Fig. 4). A pollen record in Cambará do Sul $\left(29^{\circ} 03^{\prime} 09^{\prime \prime}\right.$, $50^{\circ} 06^{\prime} 04^{\prime \prime}$ Southern Brazil) shows that Weinmannia became a common taxa in the Araucaria forest between 1520 and $1770 \mathrm{AD}$ ( $430 \mathrm{BP}$ and $180 \mathrm{BP}$ ) (Behling et al. 2004), suggesting a shift to warmer climatic conditions. These authors associated this interval with a cooler phase ( $\sim 550 \mathrm{BP}$ to $200 \mathrm{BP}$ ) called Little Ice Age (LIA), one of the most important variations of the last millennium (from the $14^{\text {th }}$ to the $19^{\text {th }}$ centuries), which is known from North Hemisphere records in the USA, described by Pederson et al. 2005, and in the Europe by Fontana, 1976, Font 1988, Ramil-Rego et al. 1994, and Luque and Julià 2002. Considering these associations, the record of Lagoa Grande suggests the presence of a warmer and probably wetter climate period (linked 
to the highest spore frequency and TOC) for the interval 370-340 BP. This can be connected with the LIA period, which has been poorly recorded in South America. Lichenometry dating of glaciers in the Cordilleras in Bolivia, $\left(16^{\circ} 17^{\prime} \mathrm{S}, 68^{\circ} 06^{\prime} \mathrm{W}\right.$; Rabatel et al. 2005) established a chronology for the LIA in that area, with a maximum occurrence in the second half of the $17^{\text {th }}$ century $(\sim 300$ BP) and finishing between 1870 and $1910 \mathrm{AD}(\sim 80$ to $40 \mathrm{BP})$. These authors concluded that the second part of the LIA could have been dry in the Andes, because tropical glaciers retreat significantly when precipitation decreases.

Many authors had identified the LIA in the tropical Andes, especially in the Cordilleras of Peru (Clapperton 1983, Rodbell 1992, Solomina et al. 2007, 2008), Argentina (Iriondo and García 1993, Piovano et al. 2002), Uruguai (Del Puerto et al. 2006), Equator (Hastenrath 1981) and Bolivia (Thompson et al. 1986, Rabatel et al. 2005). The archives for Brazil record the LIA period associated to warm climatic inferences in South region (Behling et al. 2004).

In Southern Peru, a dry climate seems to have prevailed in the $1720-1880 \mathrm{AD}(\sim 230$ to $70 \mathrm{BP})$ period (Thompson et al. 1986, Rabatel et al. 2005). In Argentina, close to Buenos Aires, a cool episode was observed (Iriondo and García 1993) and associated with the LIA period, in which an aridity episode was reported. In the same country, Laguna Mar Chiquita also shows dry conditions during the LIA period (Piovano et al. 2002).

These drier events could be correlated with the Maunder Minimum (1645-1715 AD; 305 to 235 BP), described as a climax of the LIA, when the earth gradually warms until the warming is further accelerated by anthropogenic greenhouse gases (Mann et al. 1999, Shindell et al. 2001, Youshimori et al. 2005), mainly considering an error (precision) of \pm 50 years for each radiocarbon dating in the 400-320 BP, inferred warmer and wetter climate period in this work.

\section{CONCLUSIONS}

Environmental conditions were relatively stable with the maintenance of the forest during the last 1000 years and characterized by a combination of pollen (arboreal) and isotope signals (phytoplankton and $\mathrm{C}_{3}$ land plants), which indicated humid climatic conditions for most of the period. However, the bulk and isotopic analyses of sediment core indicate significant variations, probably associated with changes in the Lagoa Grande water column, eventually linked with a wet and warm period (from $\sim 370 \mathrm{BP}$ to $\sim 340 \mathrm{BP}$ ), that was associated with the Little Ice Age (LIA) and Maunder Minimum.

\section{ACKNOWLEDGMENTS}

We gratefully acknowledge Conselho Nacional de Desenvolvimento Científico e Tecnológico (CNPq), grant 140770/02-2, for the fellowship of Soraya E.M.G. Saia, Fundação de Amparo à Pesquisa do Estado de São Paulo (FAPESP) (02/08024-1) for the financial support of this research, Paleotropique Program (UR-055 IRD-Institut de Recherche pour le Développement) for technical support, Drs. Ivo Karmann and Francisco William da Cruz, for geological and field trip contributions, and Ricardo Francischetti Garcia, for plant identification. The anonymous reviewers are also thanked for suggestions and text improvements.

\section{RESUMO}

Este estudo apresenta dados paleoambientais baseados em análises de pólen, da composição elementar e isotópica da matéria orgânica (TOC, $\mathrm{N}, \delta^{13} \mathrm{C}$ e $\delta^{15} \mathrm{~N}$ ) e datação ${ }^{14} \mathrm{C}$, de um testemunho sedimentar lacustre de $170 \mathrm{~cm}$. A amostragem foi realizada na Lagoa Grande localizada no Parque Estadual Turístico do Alto Ribeira - PETAR, Vale do Ribeira, sul do estado de São Paulo, sudeste do Brasil. As variações nas frequências relativas de pólen arbóreo (em porcentagem) apresentaram-se entre 40 e $80 \%$ ao longo de todo o testemunho. Os valores de $\delta^{13} \mathrm{C}$ variaram de $-23 \%$ à $-30 \%$, indicando a contribuição de plantas $\mathrm{C}_{3}$ (terrestres) e algas na matéria orgânica sedimentar. Os resultados de $\delta^{15} \mathrm{~N}$ apresentaram valores entre 3 e 4,5\%, também sugerindo uma mistura de algas e plantas $\mathrm{C}_{3}$. A datação ${ }^{14} \mathrm{C}$ indica idade moderna para as camadas superficiais do testemunho e uma idade de até 1030 anos AP para a camada mais profunda do mesmo. Um provável clima mais úmido para o período de $\sim 370$ anos AP até $\sim 340$ anos AP foi inferido a partir dos resultados apresentados, correspondendo a uma parte do período do Little Ice Age (LIA - Pequena Idade do Gelo).

Palavras-chave: sedimento lacustre, isótopos do $\mathrm{C}$ e N, pólen, floresta Atlântica, último milênio, Pequena Idade do Gelo. 


\section{REFERENCES}

ABSY ML. 1975. Polem e Esporos do Quaternário de Santos (Brasil). Hoehnea 5: 1-26.

Absy ML And Van Der Hammen T. 1976. Some palaeoecological data from Rondonia, Southern part of the Amazon basin. Acta Amazonica 5: 293-299.

ABsy ML ET AL. 1991. Mise em évidence de quatre phases d'ouverture de la forêt dense dans le sud-est de l'Amazonie au cours des 60000 dernières années. Première comparaison avec d'autres régions tropicales. C R Acad Sci Paris 312: 673-678.

BEHLING H. 1995a. A high resolution Holocene pollen record from Lago do Pires, SE Brazil: Vegetation, climate and fire history. J Paleolimnol 14: 235-268.

Behling H. 1995b. Investigations into the Late Pleistocene and Holocene history of vegetation and climate in Santa Catarina (S Brazil). Veg Hist Archaeobot 4(3): 127-152.

BEHLING H. 1997a. Late Quaternary vegetation, climate and fire history from the tropical mountain region of Morro de Itapeva, SE Brazil. Palaeogeogr Palaeoclimatol Palaeoecol 129(3-4): 407-422.

BEHLING H. 1997b. Late Quaternary vegetation, climate and fire history of the Araucaria forest and campos region from Serra Campos Gerais, Paraná State (South Brazil). Rev Palaeobot Palyno 97(1-2): 109-121.

BeHLing H. 1998. Late Quaternary vegetational and climatic changes in Brazil. Rev Palaeobot Palyno 99(2): 143156.

BEHLING H. 2002. South and Southeast Brazilian grasslands during Late Quaternary times: a synthesis. Palaeogeogr Palaeoclimatol Palaeoecol 177(1-2): 19-27.

Behling H, Pillar VP, Orlóci L and Bauermann GS. 2004. Late Quaternary Araucaria forest, grassland (Campos), fire and climate dynamics, studied by highresolution pollen, charcoal and multivariate analysis of the Cambará do Sul in Southern Brazil. Palaeogeogr Palaeoclimatol Palaeoecol 203(3-4): 277-297.

Blaser P, Zimmermann S, Luster J AND Shotyk W. 2000. Crotical examination of trace element enrichments and depletions in soils: $\mathrm{As}, \mathrm{Cr}, \mathrm{Cu}, \mathrm{Ni}, \mathrm{Pb}$, and $\mathrm{Zn}$ in Swiss forest soils. Sci Total Environ 249: 257-280.

CAmpanha GC And SADOwski GR. 1999. Tectonics of the Southern portion of the Ribeira Belt (Apiaí Domain). Precambrian Res 98: 31-51.

Clapperton CM. 1983. The Glaciations of the Andes. Quaternary Sci Rev 2(2-3): 83-155.
Colinvaux P, De Oliveira PE And Patiño JEM. 1999. Amazon Pollen Manual and Atlas, Harwood Academic Publishers, The Netherlands.

Colinvaux PA, De Oliveira PE, Moreno Je, Miller MC AND Bush MC. 1996. A long pollen Record from lowland Amazonia: forest and cooling in glacial times. Science 274: 85-88.

Cour P. 1974. Nouvelle techniques de detection des flux et des retombées polliniques: étude de la sedimentation des pollens et des spores à la surface du sol. Pollen et Spores XVI: 103-104.

Del Puerto L, García-Rodríguez F, Inda H, Bracco R, CAstiñeira C AND AdAms JB. 2006. Paleolimnological evidence of Holocene climatic changes in Lake Blanca, Southern Uruguay. J Paleolimnol 36: 151-163.

FAEGRI K AND IVERSEN J. 1989. Textbook of pollen analysis. J Wiley \& Sons LTD, Chichester.

FONT I. 1988. Historia del clima en España. Cambios climaticos y sus causas. Instituto Nacional de Meteorología, Ministerio de Transportes, Turismo y Comunicaciones, Madrid, 297 p.

Fontana JM. 1976. El clima del pasado. Publ Cent Pirenaico Biol Exp 7: 103-116.

HASTENRATH S. 1981. The Glaciation of the Ecuadorian Andes. A.A. Balkema Publishers, Rotterdam, The Netherlands.

Herczeg AL, Smith AK And Dighton JC. 2001. A 120 years record of changes in nitrogen and carbon cycling in Lake Alexandrina, South Australia: C:N, $\delta^{15} \mathrm{~N}$, and $\delta^{13} \mathrm{C}$ in sediments. Appl Geochem 16: 73-84.

IRIONDO MH AND GARCÍA NO. 1993. Climatic variations in the Argentine plains during the last 18,000 years. Palaeogeogr Palaeoclimatol Palaeoecol 101: 209-220.

KARMANN I. 1994. Evolução e dinâmica atual do sistema cárstico do alto vale do Rio Ribeira de Iguape, sudeste do Estado de São Paulo. Tese (Doutorado) - Instituto de Geociências, Universidade de São Paulo, São Paulo, 228 p.

Ledru MP, Braga PIS, Soubiès F, Fournier M, MARTIN L, Suguio K AND TuRCQ B. 1996. The last 50,000 years in the Neotropics (Southern Brazil): evolution of vegetation and climate. Palaeogeogr Palaeoclimatol Palaeoecol 123(1-4): 239-257.

LEDru MP, CORdeIRo RC, RodrigueZ JML, MARTIN L, Mourguiart P, Sifeddine A And Turce B. 2001. Late-Glacial cooling in Amazonia inferred from pollen at Lagoa do Caçó, Northern Brazil. Quaternary Res 55: 47-56. 
Ledru MP, Mourguiart P, Ceccantini G, Turce B AND SIFEDDINE A. 2002. Tropical climates in the game of two hemispheres revealed by abrupt climatic change. Geology 30(3): 275-278.

LENT RM, LyONS WB, SHOWERS WJ AND JOHANNESSON KH. 1995. Late Holocene paleoclimatic and paleobiologic records from sediments of Devils Lake, North Dakota. J Paleolimnol 13(3): 193-207.

LUQUE JA AND JULIÀ R. 2002. Lake sediment response to land-use and climate change during the last 1000 years in the oligotrophic Lake Sanabria (northwest of Iberian Peninsula). Sediment Geol 148(1-2): 343-355.

Mann ME, Bradley RS And Hughes MK. 1999. Northern Hemisphere temperatures during the past millennium: Inferences, uncertainties, and limitations. Geophys Res Lett 26: 759-762.

Markgraf V AND D'Antoni HL. 1978. Pollen flora of Argentina - Modern Spore and Pollen Types of Pteridophyta, Gymnospermae, and Angiospermae. The University of Arizona Press, Tuscon.

MARTin L, FleXor J-M And Suguio K. 1995. Vibrotestemunhador leve: construção, utilização e potencialidades. Revista do Instituto de Geociências 16: 59-66.

MeYers PA. 1994. Preservation of source identification of sedimentary organic matter during and after deposition. Chem Geol 144: 289-302.

MeYERS PA. 1997. Organic geochemical proxies of paleoceanographic, paleolimnologic, and paleoclimatic processes. Org Geochem 27: 213-250.

Meyers PA. 2003. Applications of organic geochemistry to paleolimnological reconstructions: a summary of examples from the Laurentian Great Lakes. Org Geochem 34: 261-289.

Meyers PA AND IshiwATARI R. 1993. Lacustrine organic geochemistry - an overview of indicators of organic matter sources and diagenesis in lake sediments. Org Geochem 20: 867-900.

Oliveira SMB, Saia SEMG, Pessenda LCR, Favaro DIT. 2009. Lacustrine sediments provide geochemical evidence of environmental change during the last millennium in Southeastern Brazil, Chemie der Erde 69: 395-405.

Ortiz Je, Torres T, Delgado A, Julià R, Lucine M, Llamas FJ, Reyes E, Soler V and Valle M. 2004. The palaeoenvironmental and palaeohydrological evolution of Padul Peat Bog (Granada Spain) over one million years, from elemental, isotopic and molecular organic geochemical proxies. Org Geochem 35: 1243-1260.
Pederson DC, Peteet DM, Kurdyla D And GuilderSON T. 2005. Medieval Warming Little Ice Age, and European impact on the environment during the last millennium in the lower Hudson Valley, New York, USA. Quaternary Res 63(3): 238-249.

Pessenda LCR, Ribeiro AS, Gouveia SEM, Aravena R, Boulet R ANd Bendassoli JA. 2004. Vegetation dynamics during the Late Pleistocene in the Barreirinhas region, Maranhão State, northeastern Brazil, based on carbon isotopes in soil organic matter. Quaternary Res 62: 183-193.

Pessenda LCR, Ledru MP, Gouveia SEM, Aravena R, Ribeiro AS, Bendassoli JA and Boulet R. 2005. Holocene palaeoenvironmental reconstruction in northeastern Brazil inferred from pollen, charcoal and carbon isotope records. Holocene 15(6): 814-822.

Peterson BJ AND Howarth RW. 1987. Sulfur, carbon, and nitrogen isotopes used to trace organic matter flow in salt-marsh estuaries of Sapelo Island, Georgia. Limnol Oceanogr 32: 1195-1213.

Piovano EL, Ariztegui D And Moreira SD. 2002. Recent environmental changes in Laguna Chiquita (central Argentina): a sedimentary model for a highly variable saline lake. Sedimentology 49: 1371-1384.

Rabatel A, Jomelli V, Naveau P, Francou B And Grancher D. 2005. Dating of Little Ice Age glacier fluctuations in the tropical Andes: Charquini glaciers, Bolívia, $16^{\circ} \mathrm{S}$. CR Geosci 337: 1311-1322.

RAMIL-REgo P, MuÑoz-Sobrinho C, RodríGuEZ-GuiTIÁN M AND GóMEZ-Orellana L. 1994. Análisis polínico y sedimentológico de dos turberas em las sierras septentrionales de Galicia (N.O. de España). Rev Paleobio 13: 41-62.

RODBELL DT. 1992. Lichenometric and radiocarbon dating of Holocene glaciation, Cordillera Blanca, Peru. The Holocene 2: 19-29.

Roth L AND LorscheitTer ML. 1993. Palynology of a bog in Parque Nacional de Aparados da Serra, East Plateau of Rio Grande do Sul, Brazil. Quat South Am Antarct Peníns 8: 39-69.

SAIA SEMG. 2006. Reconstrução paleoambiental (vegetação e clima) no Quaternário tardio com base em estudo multi/interdisciplinar no Vale do Ribeira (sul do Estado de São Paulo). Tese de Dotorado. Universidade de São Paulo, Piracicaba, SP, Brasil, 119 p.

SAlgado-Labouriau ML, Barberi M, Ferraz-ViCENTINI KR AND PARIZZI MG. 1998. A dry climatic 
event during the late Quaternary of tropical Brazil. Rev Palaeobot Palyno 99: 115-129.

SCHIDlOWSKI M, GORZAWSKI H AND DOR I. 1994. Carbon isotopic variations in a solar pond microbial mat: role of environmental gradients as steering variables. Geochim Cosmochim Ac 58: 2289-2298.

Shindell DT, Schmidt GA, MANN ME, Rind D AND WAPPLE A. 2001. Solar forcing of regional climate change during the Maunder Minimum. Science 294: 2149-2152.

Sifeddine A, Martin L, TurcQ B, Volkmer-Ribeiro C, Soubiès F, Cordeiro RC And Suguio K. 2001. Variations of the Amazonian rainforest environment: a sedimentological record covering 30,000 years. Palaeogeogr Palaeoclimatol Palaeoecol 168(4): 221-235.

SIFEDDINE A ET AL. 2003. A 21000 cal years paleoclimatic record from Caçó Lake, northern Brazil: evidence from sedimentary and pollen analyses. Palaeogeogr Palaeoclimatol Palaeoecol 189(1-2): 25-34.

Sifeddine A, Wirrmann D, Albuquerque ALS, TurcQ B, Cordeiro RC, GURGEl MHC AND ABrÃo JJ. 2004. Bulk composition of sedimentary organic matter used in palaeoenvironmental reconstructions: examples from the tropical belt of South America and Africa. Palaeogeogr Palaeoclimatol Palaeoecol 241: 41-53.
Solomina O, Jomelli V, Kaser G, Ames A, Berger B AND POYAud B. 2007. Lichenometry in the Cordillera Blanca, Peru: "Little Ice Age" moraine chronology. Global Planet Change 59: 225-235.

Solomina O, Haeberli W, Kull C and Wiles G. 2008. Historical and Holocene glacier-climate variations: General concepts and overview. Global Planet Change 60: 01-09.

Stuiver M, Reimer P AND Braziunas TF. 1998. Highprecision radiocarbon age calibration for terrestrial and marine samples. Radiocarbon 40: 1127-1151.

THOMPSON LG, MOSLEY-THOMPsOn E, DANSGAARD W AND GROOTES PM. 1986. The little ice age as recorded in the stratigraphy of the tropical Quelcaya ice cap. Science 234: 361-364.

VAN DER HAMMEN T AND ABSy ML. 1994. Amazonia during the last Glacial. Palaeogeogr Palaeoclimatol Palaeoecol 109: 247-261.

Youshimori M, Stocker TF, Raible CC ANd Renold M. 2005. Externally forced and internal variability in ensemble climate simulations of the Maunder Minimum. Bul Am Meteorol Soc 18: 4253-4270. 